\title{
Regionally-Selective Cell Colonization of Micropatterned Surfaces Prepared by Plasma Polymerization of Acrylic Acid and 1,7-Octadiene
}

\author{
E. FILOVÁ ${ }^{1,2}$, N.A. BULLETT ${ }^{3,4}$, L. BAČÁKOVÁ ${ }^{1,2}$, L. GRAUSOVÁ ${ }^{1}, J^{\text {W. HAYCOCK }}$, $^{3}$ \\ J. HLUČILOVÁ ${ }^{5}$, J. KLÍMA ${ }^{5,6}$, A. SHARD ${ }^{3,7}$
}

${ }^{1}$ Department of Growth and Differentiation of Cell Populations and ${ }^{2}$ Centre for Cardiovascular Research, Institute of Physiology v.v.i., Academy of Sciences of the Czech Republic, Prague, Czech Republic, ${ }^{3}$ Department of Engineering Materials, University of Sheffield, Sheffield, UK, ${ }^{4}$ CellTran Ltd., The Innovation Centre, Sheffield, UK, ${ }^{5}$ Institute of Animal Physiology and Genetics, v.v.i., Academy of Sciences of the Czech Republic, Liběchov, Czech Republic, ${ }^{6}$ Center of Cell Therapy and Tissue Repair, Second Faculty of Medicine, Charles University, Prague, Czech Republic, ${ }^{7}$ National Physical Laboratory, Hampton Road, Middlesex, UK

Received February 15, 2008

Accepted September 3, 2008

On-line November 4, 2008

\section{Summary}

Micropatterned surfaces have been used as a tool for controlling the extent and strength of cell adhesion, the direction of cell growth and the spatial distribution of cells. In this study, chemically micropatterned surfaces were prepared by successive plasma polymerization of acrylic acid (AA) and 1,7-octadiene (OD) through a mask. Rat vascular smooth muscle cells (VSMC), bovine endothelial cells (EC), porcine mesenchymal stem cells (MSC) or human skeletal muscle cells (HSKMC) were seeded on these surfaces in densities from $9,320 \mathrm{cells} / \mathrm{cm}^{2}$ to 31,060 cells $/ \mathrm{cm}^{2}$. All cell types adhered and grew preferentially on the strip-like AA domains. Between day 1 and 7 after seeding, the percentage of cells on AA domains ranged from 84.5 to $63.3 \%$ for VSMC, 85.3 to $73.5 \%$ for EC, 98.0 to $90.0 \%$ for MSC, and 93.6 to $55.0 \%$ for HSKMC. The enzyme-linked immunosorbent assay (ELISA) revealed that the concentration of alpha-actin per $\mathrm{mg}$ of protein was significantly higher in VSMC on AA. Similarly, immunofluorescence staining of von Willebrand factor showed more apparent Weibel-Palade bodies in EC on AA domains. MSC growing on AA had better developed beta-actin cytoskeleton, although they were less stained for hyaluronan receptor (CD44). In accordance with this, MSC on AA contained a higher concentration of beta-actin, although the concentration of CD44 was lower. HSKMC growing on AA had a better developed alphaactin cytoskeleton. These results based on four cell types suggest that plasma polymerization is a suitable method for producing spatially defined patterned surfaces for controlled cell adhesion, proliferation and maturation.

\section{Key words}

Micropatterning - Plasma polymerization - Mesenchymal stem cells • Endothelial cells $\bullet$ Smooth muscle cells

\section{Corresponding author}

Elena Filová, PhD, Department of Growth and Differentiation of Cell Populations, Institute of Physiology, Academy of Sciences of the Czech Republic, Videnska 1083, 14220 Prague 4, Czech Republic. Fax: +420 24106 2488. E-mail: filova@biomed.cas.cz

\section{Introduction}

One of the challenges in tissue engineering is to prepare materials for controlled cell attachment, growth, and migration. Cell attachment and adhesion to the surface of biomaterials are influenced by several factors, such as chemical composition, roughness, rigidity, wettability, surface energy, electrical charge or protein adsorption (Bačáková et al. 2004). Abrupt transitions in physical-chemical properties have been successfully utilized to create discrete adhesive or non-adhesive domains for cells on micropatterned surfaces. The size and shape of the domains, and their periodicity, regulate 
the response of different cell types to the surface (Goessl et al. 2001).

Plasma polymerization is a low-temperature, solvent-free process for the deposition of thin polymeric films from small volatile organic compounds (Alexander and Duck 1998, Kettle et al. 1997). Plasma discharge causes fragmentation of the monomer employed, creating a number of chemical functional groups, and crosslinking of the fragments. This cross-linking increases the stability of the polymer, and the content of ester groups, but decreases its solubility in water. This is accompanied by a decrease in functionality, mainly the $-\mathrm{COOH}$ group content that is thought to be essential for cell adhesion on copolymers of acrylic acid (AA) and 1,7-octadiene (OD). Monomer fragmentation can be reduced by precise regulation of the deposition parameters, mainly by plasma power and monomer flow rate. AA/OD copolymers prepared by plasma polymerization have already been applied to direct adhesion of keratinocytes (Haddow et al. 1999, 2003) and ROS 17/2.8 osteoblastlike cells (Daw et al. 1998).

Synthetic polymers commonly used for constructing tissue replacements are often hydrophobic and do not allow satisfactory adhesion of cells. Patterned AA/OD copolymers with hydrophilic domains could optimize the cell delivery on the surface of a synthetic biomaterial in tissue engineering.

In this study we evaluated the adhesion and growth of rat vascular smooth muscle cells (VSMC), bovine vascular endothelial cells (EC), porcine mesenchymal stem cells (MSC) or human skeletal muscle cells (HSKMC) on strip-like micropatterned surfaces created by plasma polymerization of the monomers mentioned above, i.e. hydrophilic AA and hydrophobic OD. We observed preferential adhesion and growth of these four cell types on domains composed of acrylic acid. In addition, the maturation of cells, estimated by the concentration and arrangement of alpha-actin, beta-actin or von Willebrand factor, was usually higher on AA domains.

\section{Materials and Methods}

\section{Plasma polymerization}

$\mathrm{AA}$ and $\mathrm{OD}$ were polymerized on the inner surface of 24-well multidishes (Costar, Falcon, Becton Dickinson, Lincoln Park, NJ, USA) for cell culture experiments, and on Si wafers for XPS. The Si wafers were sonicated twice for $15 \mathrm{~min}$ each time with dichloromethane in ultrasound, once with methanol (Sigma Aldrich, UK) and dried with $\mathrm{N}_{2}$. For plasma polymerization, a glass cylindrical tube of internal diameter $10 \mathrm{~cm}$ and length $40 \mathrm{~cm}$ was used (QVF, UK). A copper coil was wound around the tube and earthed aluminium/brass flanges ended the tube connecting it with a radio frequency (RF) signal generator (Coaxial Power Systems Ltd., UK). The base pressure achieved was lower than $0.1 \times 10^{-3} \mathrm{mBar}$ and an operating pressure of $6.0 \times 10^{-3}$ and $8.0 \times 10^{-3} \mathrm{mBar}$ was employed for acrylic acid and 1,7-octadiene, respectively. The leak rate was less than $0.01 \mathrm{~cm}^{3}{ }_{\text {stp }} \mathrm{min}^{-1}$. The monomer for polymerization was placed in round-bottomed flasks, connected to the reactor vessel via needle valves through one of the flanges. We used flow rate $2 \mathrm{~cm}^{3} \mathrm{stp} \mathrm{min}^{-1}$ and time of exposure $15 \mathrm{~min}$ and $1 \mathrm{~min}$ for AA and OD polymerization, respectively. Plasma deposition for 15 min was used for preparing control surfaces composed of AA or OD without microdomains (referred to as C_AA or C_OD, respectively). The plasma was initiated and sustained by a radiofrequency (RF) power source of frequency $13.56 \mathrm{MHz}$. Discharge powers of $5 \mathrm{~W}$ and $10 \mathrm{~W}$ were used for AA and OD, respectively. Impedance matching was used to ensure that the reflected RF power was minimized. The copper coil electrode is generally referred to as inductive coupling as opposed to capacitative coupling which would be two parallel plate electrodes. However, it has been shown that in this system, a large proportion of the energy coupling is capacitative due to the fact that the end flanges are earthed and also act as an electrode (Haddow et al. 1999).

After polymerization of the first polymer, AA, in the form of a continuous layer on the dish bottom, the OD was polymerized through a mask consisting of a copper transmission electron microscope grid (Sjostrand Copper $3.05 \mathrm{~mm}$, Athene Grids, UK), with strip-like gaps that were 75 and $150 \mu \mathrm{m}$ in width and 67.5 or $135 \mu \mathrm{m}$ apart. The AA strips occupied $47 \%$ of the resulting patterned surface.

$X$-ray photoelectron spectroscopy

X-ray photoelectron spectroscopy (XPS) analyses of the polymer surfaces polymerized on $\mathrm{Si}$ wafers were performed using a VG CLAM 2 (VG, UK) $\mathrm{X}$-ray photoelectron spectrometer. XPS was employed in the constant analyzer energy mode using nonmonochromatic Mg Ka X-rays with $1253.6 \mathrm{eV}$ energy. Widescan spectra over the binding energy range 0-1100 eV were acquired using a pass energy of $100 \mathrm{eV}$ 
from each sample. Detailed spectra of the $\mathrm{C} 1 \mathrm{~s}$ core levels were taken using $20 \mathrm{eV}$ pass energy. The relative sensitivity factors were experimentally determined from standard polymers during a routine monthly XPS calibration procedure. Peak fitting of the $\mathrm{C} 1 \mathrm{~s}$ core line was carried out using WinESCA software (Scienta, Uppsala, Sweden), using a linear background subtraction and mixed Gaussian-Lorentzian peak shapes. The chemical shifts for $\mathrm{C} 1 \mathrm{~s}$ environments were taken from the literature (Briggs 1998).

\section{Condensation of water droplets}

The presence of the pattern on the surface was confirmed by visualization of microscopic droplets of water condensed on to the material surface. Pictures of the patterned surface were taken immediately after wetting the surface by exposure of the sample to a humid atmosphere (phase-contrast microscope, Olympus IX51, Japan).

\section{Adsorption of collagen on to the surface}

A solution of collagen IV conjugated with Oregon Green 488 (Molecular Probes, Eugene, OR, U.S.A.) was diluted in phosphate-buffered saline (PBS) to a concentration of $1 \mu \mathrm{g} / \mathrm{ml}$. The collagen solution $(0.5 \mathrm{ml})$ was poured into wells with polymerized surfaces and incubated for $24 \mathrm{~h}$ at $4{ }^{\circ} \mathrm{C}$, washed three times with PBS and digital images were captured under an epifluorescence microscope (Olympus IX51, digital camera DP70, Japan).

\section{Contact angle measurement}

The advancing water contact angles were measured on plasma polymer coated coverslips using the sessile drop method. A $2 \mu 1$ drop of distilled water was placed on the surface, and the angles of the tangents to the points of contact were measured using a goniometer (Ramë-Hart, NJ, U.S.A.). Two further drops were added, and the contact angle was measured after each addition. For each surface, two separate points were analyzed on three different surfaces.

\section{Cells and culture conditions}

VSMC were derived from the intima-media complex of the thoracic aorta of eight-week-old male Wistar SPF rats by the explantation method (Bačáková and Kuneš 1995) and used in the 4th passage. The endothelial cells (EC) originated from bovine pulmonary artery (line CPAE ATCC CCL-209, Rockville, MA,
USA). Both cell types were seeded at a concentration of 31,060 cells $/ \mathrm{cm}^{2}$ in $1.5 \mathrm{ml}$ of the following media: for VSMC, Dulbecco's Modified Eagle's Medium (Sigma, St. Louis, MO, USA; Cat No. D5648), supplemented with $10 \%$ of fetal bovine serum (FBS; Sebak GmbH, Aidenbach, Germany) and $40 \mu \mathrm{g} / \mathrm{ml}$ of gentamycin (LEK, Ljubljana, Slovenia) was used, and the endothelial cells were grown in Minimum Essential Eagle Medium with $2 \mathrm{mM}$ L-glutamin, Earle`s BSS with $1.5 \mathrm{~g} / 1$ sodium bicarbonate, $0.1 \mathrm{mM}$ non-essential amino acids, $1.0 \mathrm{mM}$ sodium pyruvate (all chemicals from Sigma) and $20 \%$ of FBS. EC did not adhere completely; therefore the medium was replaced in EC cultures $24 \mathrm{~h}$ after seeding in order to remove the non-adherent cells.

Mesenchymal stem cells (MSC) were derived from a pig using the following procedure. Bone marrow blood was aspirated from os illium (tuber coxae, ala ossis illii) into a $10 \mathrm{ml}$ syringe with $4 \mathrm{ml}$ Dulbecco's Phosphate Buffered Saline (PBS) with $2 \%$ Fetal Bovine Serum (FBS, StemCell Technologies) and 5 IU heparin $/ \mathrm{ml}$ connected with a hypodermic needle $(20 \mathrm{G} / 40 \mathrm{~mm})$. The bone marrow blood (about $20 \mathrm{ml}$ ) was deposited over $15 \mathrm{ml}$ of Ficoll-Paque PLUS (StemCell Technologies). After centrifugation at $400 \mathrm{~g}$ for $30 \mathrm{~min}$ at room temperature, the dense gradient resulted in separation of erythrocytes and granulocytes as a pellet in the bottom part of the tube, while mononuclear cells were situated (located) in an opalescent layer between the lower Ficoll and the upper blood plasma. This layer was taken out, washed in a culture medium (see below) and used for propagation under in vitro conditions. Cells were seeded in tissue culture flasks at a density of approximately $5 \times 10^{5}$ cells $/ \mathrm{cm}^{2}$ and cultured at $37^{\circ} \mathrm{C}$ in a humidified atmosphere with $5 \%$ of $\mathrm{CO}_{2}$. The culture medium was an $\alpha$-MEM medium (GIBCO) supplemented with $10 \%$ FBS (Sigma) and gentamycin (50 mg/ml, Sigma). After $24 \mathrm{~h}$ of culture, the non-adherent cells were removed, and during subsequent cultivation ( 3 weeks), the medium was exchanged every third day. MSC were seeded in a density of 9320 cells $/ \mathrm{cm}^{2}$ in $1.5 \mathrm{ml}$ of $\alpha$-MEM (GIBCO) medium supplemented with $10 \%$ fetal bovine serum (FBS; Sebak $\mathrm{GmbH}$ ) and $40 \mu \mathrm{g} / \mathrm{ml}$ of gentamycin (LEK). The presence of surface markers characteristic for MSC was then evaluated using flow cytometry. From passage 1 to 5 , the cells were homogeneously stained for mesenchymal stem cell markers CD29, CD44 and CD90. At the same time, the cells were negative for CD45, i.e. a marker of leukocytes. Cells were also positively stained for markers CD105 and CD147, but the signal tended to 
decrease in subsequent passages. The concentration and spatial distribution of the hyaluronan receptor CD 44, i.e., an adhesion molecule which might influence the cellmaterial interaction, was then chosen as a marker of the further behavior of MSC on AA/OD patterned surfaces.

Human skeletal muscle cells (HSKMC) were represented by commercially available primary cultures isolated from human tissues (Provitro $\mathrm{GmbH}$, Berlin, Germany). The cells were seeded in a density of 18,640 cells $/ \mathrm{cm}^{2}$ in $1.5 \mathrm{ml}$ of skeletal muscle cell growth medium (Provitro GmbH, Cat. No. 201 0602) and used in passages 2 to 4 .

\section{Flow cytometry of mesenchymal stem cells}

Trypsinized cells were washed in a blocking solution containing PBS supplemented with $10 \%$ FBS, $1 \%$ gelatin and $0.1 \%$ sodium azide. $5 \times 10^{5}$ cells were incubated in $100 \mu \mathrm{l}$ of the blocking solution and $1 \mu \mathrm{g}$ of primary $\mathrm{mAb}$ for $30 \mathrm{~min}$ at $4{ }^{\circ} \mathrm{C}$. The panel of antibodies used was: anti-CD29 (clone MEM-101A), anti-CD105 (clone MEM 229), anti-CD147 (clone MEM-M6/2; all three antibodies from Exbio Praha a.s., Prague, Czech Republic), anti-CD44 (clone IM7), anti-CD90 (clone 5E10; both antibodies from BD Biosciences, San Jose, CA, USA), anti-CD45 (clone K252-1E4, AbD Serotec, Kidlington, UK). After two washes in a washing solution (PBS with $1 \%$ gelatin and $0.1 \%$ azide), the cells were incubated with a goat anti-mouse Alexa Fluor 488 secondary antibody (Molecular Probes) in the blocking solution mentioned above (dilution 1:1000) for $30 \mathrm{~min}$ at $4{ }^{\circ} \mathrm{C}$. Secondary antibody was washed out twice in the washing solution, and cell pellets were resuspended in the washing solution containing propidium iodide for determination of supravitality of the cells. Cells were then analyzed by FACScalibur, and the data was processed using CellQuest software (BD Biosciences). CD44 staining was performed with PE conjugated primary antibody using similar conditions and buffers as mentioned above; isotype controls were included and served as background controls.

\section{Cell number, morphology and growth curves}

The number and shape of cells on the tested surfaces were evaluated on 9-15 micrographs taken under a phase-contrast microscope (Olympus IX51, Japan) equipped with a digital camera DP70. The cell population densities, measured from six hours to seven days after seeding were used for constructing the growth curves.

\section{Bromodeoxyuridine labeling index}

Three days after seeding, the cells were incubated with $40 \mu \mathrm{M}$ 5-bromo-2-deoxy-uridine (BrdU; $30 \mathrm{~min}, 37^{\circ} \mathrm{C}$ ), washed with PBS, fixed with precooled $\left(-20{ }^{\circ} \mathrm{C}\right) 70 \%$ ethanol for $15 \mathrm{~min}$ and their DNA was partially denatured by treatment with $3 \mathrm{M} \mathrm{HCl}$ (20 min, room temperature). The samples were then washed in $0.1 \mathrm{M}$ sodium tetraborate ( $\mathrm{pH} 8.5,10 \mathrm{~min}$ ) and nonspecific binding sites were blocked by $3 \%$ FBS in PBS with $0.3 \%$ Triton X-100 (Sigma) for $30 \mathrm{~min}$. The newly synthesized DNA was immunolabeled with an anti-BrdU mouse monoclonal antibody (Exbio a.s., Cat. No. 11-286_M001; dilution 1:200) for $80 \mathrm{~min}$ at room temperature. Biotin-conjugated goat anti-mouse IgG (Fab specific, Cat. No. B-0529; dilution 1:300) and ExtrAvidin ${ }^{\circledR}$-Peroxidase (Sigma, Cat. No. E-2886; dilution 1:100) were used in the subsequent steps. All three chemicals were diluted in PBS with $3 \%$ FBS and $0.3 \%$ Triton X-100 and applied for $60 \mathrm{~min}$ at room temperature. Then the solution containing a chromogen, 3, 3'-diaminobenzidine ( $1 \mathrm{mg})$, TRIS buffer ( $2 \mathrm{ml})$, and a peroxidase substrate, $1 \%$ peroxide $(0.07 \mathrm{ml})$ was added. The color was intensified by $8 \% \mathrm{NiCl}_{2}$ in $\mathrm{H}_{2} \mathrm{O}$ for $5 \mathrm{~min}$. The cells were counterstained with $0.5 \%$ light green and the percentage of BrdU-labeled nuclei was assessed in a phase-contrast microscope. For each experimental group, 11-15 randomly chosen microscopic fields were evaluated $\left(0.138 \mathrm{~mm}^{2}\right.$, obj. 20x, 13-66 cells per field).

Immunofluorescence staining of alpha-actin, von Willebrand factor, beta-actin, CD44 and talin

Maturation of VSMC and EC was studied using immunofluorescence staining of markers of differentiation, such as alpha-actin and von Willebrand factor for VSMC and EC, respectively. Mesenchymal stem cells were stained for beta-actin, CD44 and talin, skeletal muscle cells for alpha- and beta-actin. The cells were fixed in $70 \%$ cold methanol $\left(5 \mathrm{~min},-20{ }^{\circ} \mathrm{C}\right)$, pretreated with $3 \%$ FBS in PBS containing $0.1 \%$ Triton $\mathrm{X}-100$ (20 min at room temperature) and incubated with primary antibodies, i.e. monoclonal anti-alpha smooth muscle actin (mouse IgG2a isotype, clone 1A4, Sigma, Cat. No. A2547, dilution 1:200), rabbit anti-human von Willebrand factor (Sigma, Cat. No. F3520; dilution 1:100), monoclonal anti-beta-actin, clone AC-15, mouse ascites fluid (Sigma, Cat. No. A 5441; dilution 1:200), purified rat anti-pig CD44H (BD Biosciences, Cat. No. 551542; dilution 1:200) or monoclonal anti-talin (clone 8D4, Sigma, Cat. No. T3287, dilution 1:200). All 
Table 1. Enzyme-linked immunosorbent assay (ELISA) of alpha-actin, beta-actin, talin, von Willebrand factor or CD44 in vascular smooth muscle cells (VCMC), endothelial cells (EC), mesenchymal stem cells (MSC) or human skeletal muscle cells (HSKMC).

\begin{tabular}{|c|c|c|c|c|c|}
\hline $\mathbf{C} \_\mathbf{A A}$ & $\begin{array}{c}\text { C_OD } \\
\left(\% \bar{C} C_{-} \mathbf{A A}\right)\end{array}$ & $\mathbf{C}_{-} \mathbf{A} \mathbf{A}$ & $\begin{array}{c}\text { C_OD } \\
\left(\% \bar{C} \mathbf{C}_{-} \mathbf{A A}\right)\end{array}$ & $\mathbf{C}_{-} \mathbf{A A}$ & $\begin{array}{c}\text { C_OD } \\
\left(\% \bar{C} C_{-} \mathbf{A A}\right)\end{array}$ \\
\hline \multicolumn{2}{|c|}{ VSMC (alpha-actin) } & \multicolumn{2}{|c|}{ VSMC (beta-actin) } & \multicolumn{2}{|c|}{ VSMC (talin) } \\
\hline $100.0 \pm 4.2$ & $77.1 \pm 9.2 *$ & $100.0 \pm 12.4$ & $83.5 \pm 17.9$ & $100.0 \pm 10.7$ & $82.9 \pm 5.1$ \\
\hline \multicolumn{2}{|c|}{ EC (von Willebrand factor) } & \multicolumn{2}{|c|}{ EC (beta-actin) } & \multicolumn{2}{|c|}{ EC (talin) } \\
\hline $100.0 \pm 3.5$ & $92.0 \pm 6.9$ & $100.0 \pm 9.95$ & $123.4 \pm 22.8$ & $100.0 \pm 6.0$ & $97.9 \pm 2.9$ \\
\hline \multicolumn{2}{|c|}{ MSC (CD44) } & \multicolumn{2}{|c|}{ MSC (beta-actin) } & \multicolumn{2}{|c|}{ MSC (talin) } \\
\hline $100.0 \pm 12.0$ & $152.3 \pm 3.2 *$ & $100.0 \pm 6.97$ & $75.2 \pm 7.8^{*}$ & $100.0 \pm 5.8$ & $95.8 \pm 6.0$ \\
\hline \multicolumn{2}{|c|}{ HSKMC (alpha-actin) } & \multicolumn{2}{|c|}{ HSKMC (beta-actin) } & \multicolumn{2}{|c|}{ HSKMC (talin) } \\
\hline $100.0 \pm 10.0$ & $95.8 \pm 7.5$ & $100.0 \pm 12.9$ & $114.1 \pm 16.7$ & $100.0 \pm 5.8$ & $110.9 \pm 8.5$ \\
\hline
\end{tabular}

The absorbance on C_OD was expressed as a percentage of the values obtained in cells on C_AA. Mean \pm SEM from 3 to 8 measurements, ANOVA, * $\mathrm{p} \leq 0.05$ compared to C_AA.

antibodies were diluted in PBS and applied for $80 \mathrm{~min}$. As secondary antibodies, we used goat anti-mouse IgG fluorescein isothiocyanate (FITC) conjugate (Sigma, Cat. No. F-8771; dilution 1:200), goat anti-rabbit IgG FITC conjugate (Sigma, Cat. No. F-1262, dilution 1:40), Alexa Fluor $^{\circledR} 488$-conjugated (F(ab')2 fragment of goat antimouse $\operatorname{IgG}(\mathrm{H}+\mathrm{L})$, or Alexa Fluor ${ }^{\circledR} 488$-conjugated goat anti-rat IgG $(\mathrm{H}+\mathrm{L})$ (Molecular Probes, Cat. No. A11017 or A11006, dilution 1:400 or 1:200), respectively. The secondary antibodies were applied for $1 \mathrm{~h}$ at room temperature. The cells were mounted in Gel/mount ${ }^{\mathrm{TM}}$ (Biomeda Corp., CA, U.S.A.) and evaluated under an epifluorescence microscope (Olympus IX51, digital camera DP70, Japan).

\section{Enzyme-linked immunosorbent assay (ELISA)}

The concentration of alpha-actin, beta-actin, von Willebrand factor, hyaluronan receptor (CD44) and talin in cell lysates (per mg of protein) were measured after threeday cultivation on continuous non-patterned $\mathrm{C}_{-} \mathrm{AA}$ and C_OD surfaces (Table 1). The cells were detached by trypsinization (trypsin-EDTA, Sigma, Cat. No. T4174; $5 \mathrm{~min}, 37{ }^{\circ} \mathrm{C}$ ), resuspended in PBS, centrifuged, resuspended in PBS $\left(10^{6}\right.$ cells $\left./ \mathrm{ml}\right)$ and kept in a freezer at $70{ }^{\circ} \mathrm{C}$ overnight. The cell homogenates were then prepared by ultrasonication for $10 \mathrm{~s}$ by a sonicator (Bandelin Sonoplus HD 3080, Bandelin Electronic $\mathrm{GmbH}$, Germany), and the total protein content was measured using a modified method by Lowry. Aliquots of the cell homogenates corresponding to $1-50 \mu \mathrm{g}$ of protein in $50 \mu \mathrm{l}$ of water were adsorbed on 96-well microtiter plates
(Maxisorp, NUNC, Roskilde, Denmark) at $4{ }^{\circ} \mathrm{C}$ overnight. After washing twice with PBS $(100 \mu \mathrm{l} /$ well $)$, the nonspecific binding sites were blocked by $0.02 \%$ gelatine in PBS (60 min, $100 \mu \mathrm{l} /$ well). The primary monoclonal antibodies (see above), diluted in PBS, anti-alpha smooth muscle actin (dilution 1:250), monoclonal anti-beta-actin (dilution 1:200), anti-human von Willebrand factor (dilution 1:200), or purified rat anti-pig CD44H (dilution 1:250) and monoclonal anti-talin (dilution 1:200) were applied for $60 \mathrm{~min}$ at room temperature $(50 \mu \mathrm{l} /$ well $)$. As secondary antibodies, goat anti-mouse $\mathrm{F}(\mathrm{ab})_{2} \quad \mathrm{IgG}$ fragment, goat anti-rabbit IgG (Sigma, Cat. No. A3682 and A9169, dilution 1:1000 and 1:5000, respectively); or goat anti-rat IgG polyclonal antibody conjugated with peroxidase (Serotec, UK, Cat. No. STAR72, dilution 1:500) were used (diluted in PBS, $50 \mu \mathrm{l} /$ well, incubation $45 \mathrm{~min}$ ). This step was followed by double washing in PBS with Triton X-100 (0.1\%) and orthophenylendiamine reaction (Sigma, concentration $2.76 \mathrm{mM}$ ) using $0.05 \%$ $\mathrm{H}_{2} \mathrm{O}_{2}$ in $0.1 \mathrm{M}$ phosphate buffer ( $\mathrm{pH}$ 6.0, dark place, $100 \mu \mathrm{l} /$ well). The reaction was stopped after $10-30 \mathrm{~min}$ by $2 \mathrm{M} \mathrm{H}_{2} \mathrm{SO}_{4}(50 \mu \mathrm{l} /$ well) and the absorbance was measured at $492 \mathrm{~nm}$ by a Wallac VICTOR ${ }^{2}, 1420$ Multilabel Counter (PerkinElmer ${ }^{\mathrm{TM}}$ LifeSciences, Belgium).

\section{Statistical analysis}

Quantitative data was presented as mean \pm SEM. Statistical analyses were performed using SigmaStat (Jandel Corporation, U.S.A.). Multiple comparison procedures were carried out by the ANOVA, StudentNewman-Keuls method, a parametric test that compares 

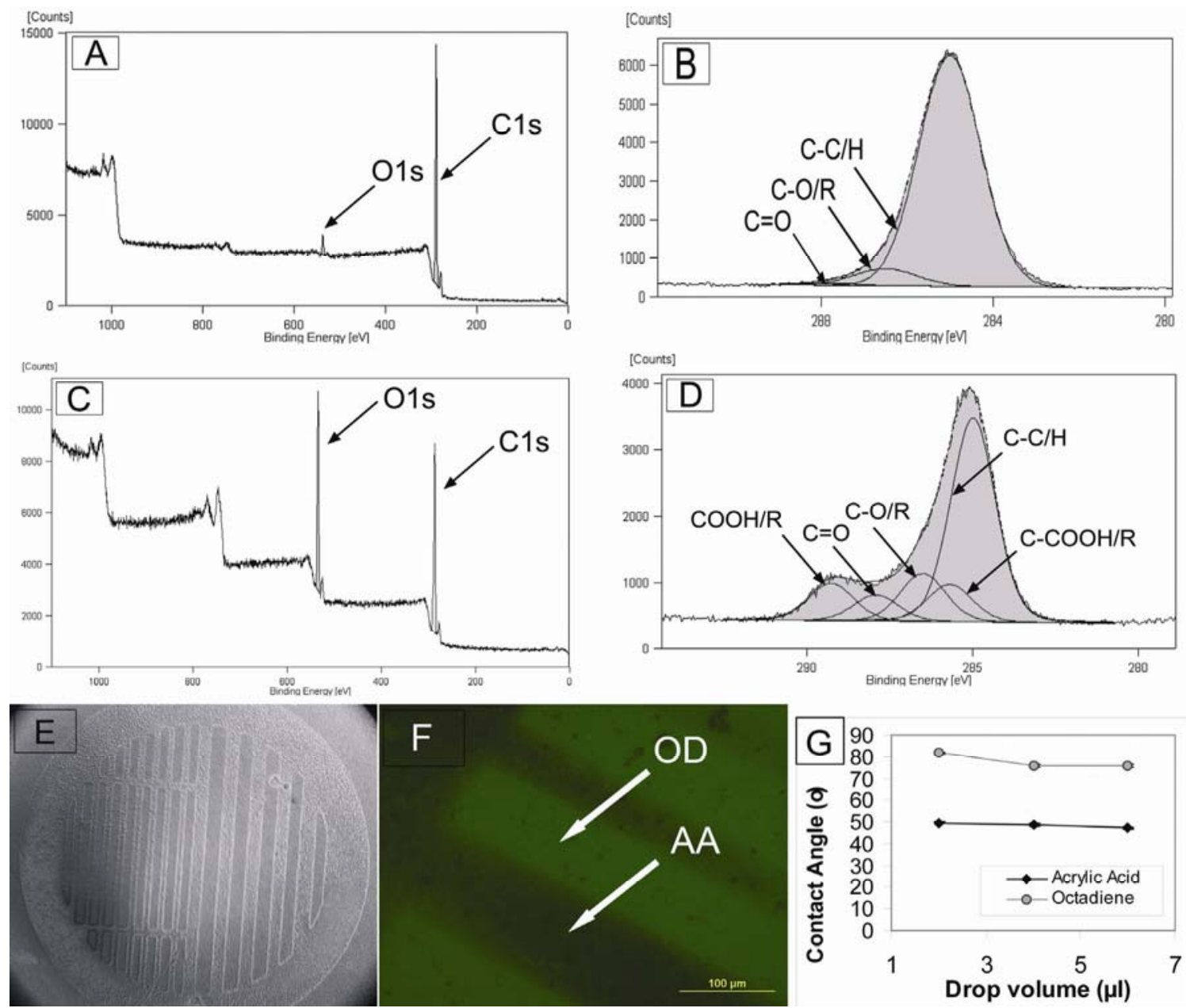

Fig. 1. A, B. Wide (A) and narrow (B) XPS spectrum of polymerized 1,7-octadiene. C, D. Wide (C) and narrow (D) spectrum of polymerized acrylic acid. E, F. Visualization of a micropatterned surface by condensation of water, objec-tive $4 x(E)$; adsorption of collagen IV, objective 20x (F). G. Advancing water contact angles on polymerized acrylic acid and 1,7-octadiene using the sessile drop method (G).

the effect of a single factor on the mean of two or more groups. The value $p \leq 0.05$ was considered significant.

\section{Results}

\section{Concentration of chemical functional groups}

Only two elements were detected by XPS, namely carbon and oxygen $(8 \% \mathrm{O}$ and $42 \% \mathrm{O}$ for OD and AA, respectively). The chemically shifted species observed in $\mathrm{C} 1 \mathrm{~s}$ spectra can thus be readily interpreted as belonging to oxygen-containing functionalities. Surfaces prepared by polymerization of OD (Fig. 1A, B) contained $92 \% \mathrm{C}-\mathrm{C} / \mathrm{H}$ groups, $7 \% \mathrm{C}-\mathrm{O} / \mathrm{R}$ groups, and $1 \% \mathrm{C}=\mathrm{O}$ groups. Polymeric AA (Fig. 1C, D) contained $\mathrm{C}-\mathrm{C} / \mathrm{H}$ (58\%), C-COOH/R (11\%), C-OH/R (13\%), C=O (7\%).

Condensation of water droplets and collagen IV adsorption

Water droplets condensed on the surface proved the presence of a micropatterned structure (Fig. 1E). As indicated by the intensity of the fluorescence, Oregon Green 488-conjugated collagen IV was more adsorbed on to OD domains (OD_lines) than on to AA domains (AA_lines, Fig. 1F).

\section{Contact angle}

The figure shows the results of contact angle measurements of the plasma polymer surfaces. The hydrocarbon (octadiene) surface was relatively hydrophobic, as expected, having an advancing contact angle of $75.7 \pm 0.6^{\circ}$, measured in the plateau region of the graph. The acrylic acid surface was more hydrophilic, with an advancing contact angle measured as $47.8 \pm 0.6^{\circ}$ (Fig. 1G).

Adhesion and growth of VSMC on micropatterned AA/OD surfaces

During the first day after seeding VSMC (Figs 


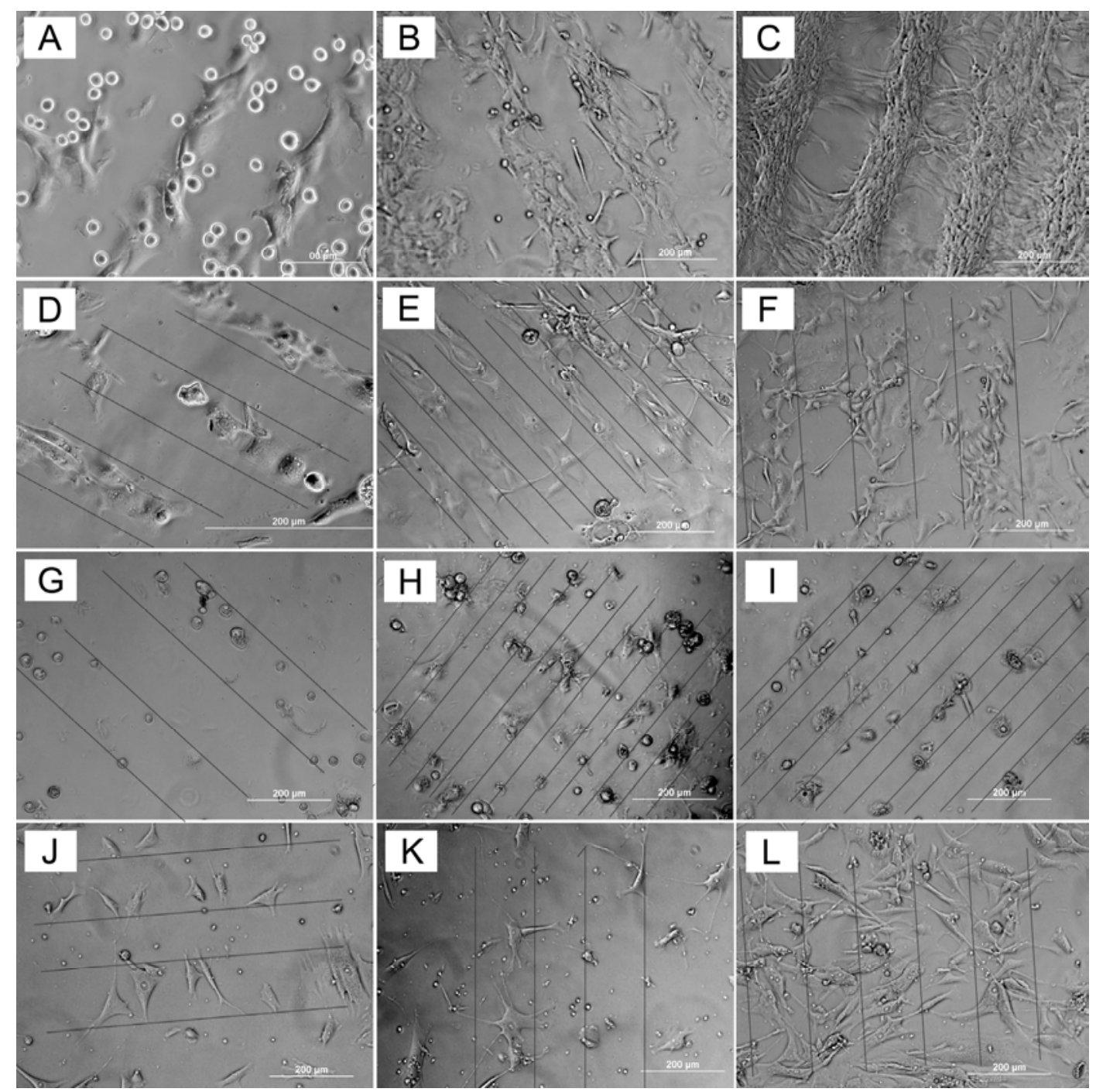

Fig. 2. Vascular smooth muscle cells (A-C), endothelial cells (D-F), mesenchymal stem cells (G-I) or skeletal muscle cells (J-L) on micropatterned surfaces with acrylic acid and 1,7-octadiene domains, 6 hours (A, D, G, J), 24 hours (B, E, H, K) and 5 days (C, F, I, L) after seeding. Lines in pictures (D-L) indicate AA strips on the patterned surface. Olympus IX50, digital camera DP70, obj. $\times 20(\mathbf{A}$ and D) and $\times 10$ (B-C, E-L). Bar: A: $100 \mu \mathrm{m}$, B-L: $200 \mu \mathrm{m}$.

$2 \mathrm{~A}$ and $2 \mathrm{~B}$ ) adhered preferentially on the strip-like AA_lines created by plasma polymerization. The cells were spindle-shaped and oriented along the strips. Although the AA strips occupied only about $47 \%$ of the total surface area, the percentage of cells adhered on these domains amounted to $84.5 \pm 3.1 \%$ (Fig. 3A). The steepest rise of the growth curve of VSMC on AA_lines from day 1 to 2 showed the earliest onset of cell proliferation on these domains (Fig. 3B). Moreover, VSMC growing on AA_lines was most active in DNA synthesis, as indicated by the highest BrdU labeling index of $12.2 \pm 1.3 \%$ measured on day 3 after seeding, compared to significantly lower values of $6.5 \pm 1.4 \%$ and $7.5 \pm 1.07 \%$ on OD_lines and C_OD, respectively. As a result, the population densities of VSMC on AA_lines during 7-day cultivation were significantly higher than those on OD_lines (Fig. 3B). The density of VSMC on AA_lines even exceeded the density on a pure C_AA surface up to day 3 after seeding. The differences in cell adhesion and growth on AA and OD were more apparent on $\mathrm{AA}$ and $\mathrm{OD}$ strips than on continuous $\mathrm{AA}$ and $\mathrm{OD}$ surfaces. OD did not entirely inhibit cell adhesion and growth, but the cells reached only relatively low densities on it. From day 1 to 7 after seeding, the densities on OD_lines were about 4.3 times lower than the values on AA_lines, and the densities on C_OD were $\sim 1.7$ times lower than on the corresponding C_AA surfaces. In addition, by day five after seeding, $54 \%$ of VSMC growing on OD_lines detached from the surface and floated in the culture media. On the other hand, it was observed that cells could span adjacent OD lines in order to reach a neighboring AA domain (Fig. 2C). As a result, 

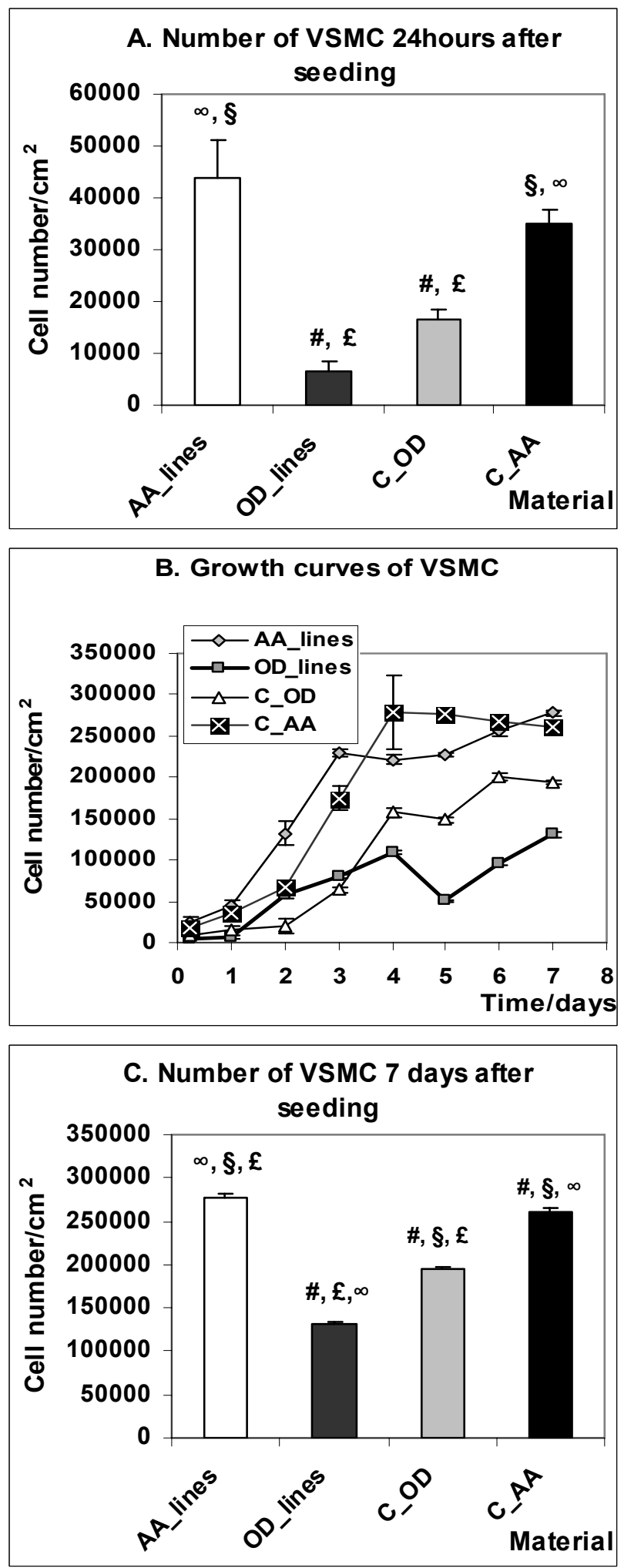

Fig. 3. Population density of vascular smooth muscle cells (VSMC) on strips formed by AA (AA_lines), OD (OD_lines), on control surface without microdomains formed by $A A\left(C_{-} A A\right)$ and OD (C OD) on day 1 (A) and on day 7 after seeding (C). Growth curves (B) of VSMC cultivated on these surfaces. Mean \pm SEM from 9 to 15 measurements, ANOVA; \#, $\S, \ldots, \infty \leq 0.05$ in comparison with AA_lines, OD_lines, C_AA and C_OD, respectively.
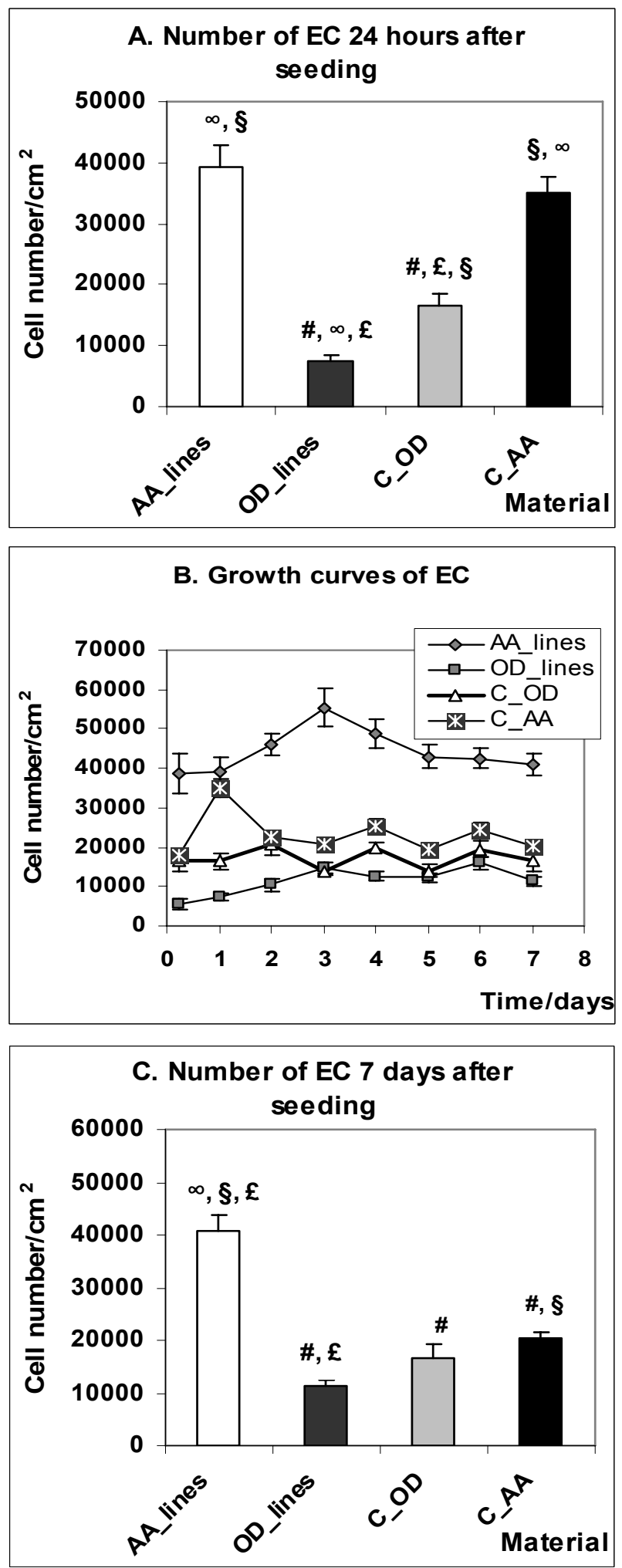

Fig. 4. Population density of vascular endothelial cells $(E C)$ on strips formed by AA (AA_lines), OD (OD_lines), on a control surface without microdomains formed by $A A$ (C_AA) and $O D$ (C_OD) on day 1 (A) and on day 7 after seeding (C). Growth curves (B) of EC cultivated on these surfaces. Mean \pm SEM from 9 to 15 measurements, ANOVA; \#, $\S, £, \infty$ : $p \leq 0.05$ in comparison with AA_lines, OD_lines, C_AA and C_OD, respectively. 
the difference in cell population densities between AA and OD lines gradually decreases. On day 7 after seeding, the percentage of cells on AA_lines decreased to $63.3 \pm 2.2 \%$, although this difference still remained significant (Fig. 3C).

Adhesion and growth of EC on a micropatterned AA/OD surface

Similarly to VSMC, endothelial cells also adhered and grew preferably on AA_lines (Figs 2D-F). Six and 24 hours after seeding, the percentage of cells on these domains was $85.3 \pm 3.8$ and $80.7 \pm 2.5$, respectively (Fig. 4A). On day 1, the cells were mostly elongated along the direction of AA_lines, and in the following days they acquired a cobblestone-like appearance. The growth curves revealed that from day 1 to 7 after seeding, the cell number increased apparently only on AA_lines, whereas on the other surfaces, the changes in the cell number were minimal (Fig. 4B). The BrdU labeling index of EC amounted to $31.5 \pm 3.4 \%$ on AA_lines, and was significantly higher than that on all other surfaces where the values ranged from $6.9 \pm 0.9 \%$ to $13.5 \pm 1.5 \%$. The highest population density of EC was observed on AA_lines, the lowest on OD_lines each day during 7-day cultivation (Figs 4 A-C). The difference in cell densities on AA and OD strips was much more apparent than that between surfaces with a continuous layer of AA or OD. On AA_lines, the densities were $\sim 4.5$ times higher than on OD_lines, whereas on C_AA, the values were only 1.6. On day 7 after seeding, the percentage of $\mathrm{EC}$ growing on AA_lines was $73.5 \pm 1.8 \%$ (Fig. 4C).

\section{Adhesion and growth of MSC on a micropatterned} AA/OD surface

Mesenchymal stem cells showed the most apparent preferential adhesion and growth on AA_lines (Figs 2G-I). Six and 24 hours after seeding, the percentages of MSC growing on AA domains reached even $98.0 \pm 1.0$ and $90.2 \pm 3.8$, respectively. The cells growing on AA_lines were relatively less spread, often rounded, and no cell elongation, observed in VSMC and EC, along the strips was present (Fig. 2G-I). The highest cell population density was observed on AA domains during 7-day cultivation, and it was significantly higher than that on OD_lines (14.3 and 8.6 times higher on day 1 and 7 after seeding, respectively), as well as on both control non-patterned C_AA and C_OD samples (Fig. 5A). The lowest cell population density was found on OD_lines on day 1. Although the growth of MSC was very slow, as apparent from the growth curves (Fig. 5B), cells on AA_lines incorporated BrdU significantly more (BrdU labeling index of $50.5 \pm 6.6 \%$ ) than on OD_lines, and C_OD $(17.7 \pm 7.1 \%$, and $17.0 \pm 4.7 \%$, respectively). The number of cells also increased on C_AA (Figs 5B and $5 \mathrm{C}$ ) during one week of cultivation, while on OD_lines this number stagnated from day 1 to 7 . Pure C_OD did not allow cell growth, as the cell number decreased from day 1 to 7 (Fig. 5B). On day 7, the percentage of MSC growing on AA_lines was 90.0 \pm 1.4 .

\section{Adhesion and growth of HSKMC on a micropatterned AA/OD surface}

Human skeletal muscle cells also adhered and grew preferentially on AA domains. Six hours and one day after seeding, 84.6 \pm 1.6 and $93.6 \pm 2.0 \%$ of HSKMC were attached to these domains, respectively. Up to day 2 after seeding, the highest cell population densities were found on AA_lines, (Fig. 6A, B). DNA synthesis on day 3 after seeding was also highest on AA_lines, where it reached $34.8 \pm 5.1 \%$ of BrdU positive cells, compared to significantly lower values of $24.5 \pm 6.4 \%$ on OD_lines, and $28.2 \pm 6.0 \%$ on C_OD. However, growth curves showed that between days 5 to 7 after seeding, HSKMC proliferation was quickest on continuous non-patterned C_AA surfaces (Fig. 6B). As a result, the cells on C_AA reached the highest cell population density on day 7 , which was significantly higher than the values on the other surfaces (Figs 6B-C). Moreover, on C_AA surfaces, the cells were markedly better spread than on the other surfaces, although the cells were polygonal in shape on all tested surfaces (Figs 7M-O). Surprisingly, on day 7 , the cell densities on both AA_lines and OD_lines were almost equal, with only $55.0 \%$ of HSKMC growing on AA_lines.

Immunoflurescence staining of alpha-actin, von Willebrand factor, beta-actin, CD44, and talin

VSMC growing on all surfaces had a welldeveloped alpha-actin cytoskeleton. Cells growing on OD were more spread, and thus it was easier to observe actin filaments after staining (Figs 7A-C). In EC, von Willebrand factor, stored in Weibel-Palade bodies, was stained more intensively in cells growing on AA compared to OD (Figs 7D-F, both strips and continuous layers). On micropatterned surfaces, positively stained EC created strips corresponding to AA_lines (Fig. 7 D).

Surprisingly, CD44 was more intensively stained in MSC growing on C_OD, with the brightest staining at 

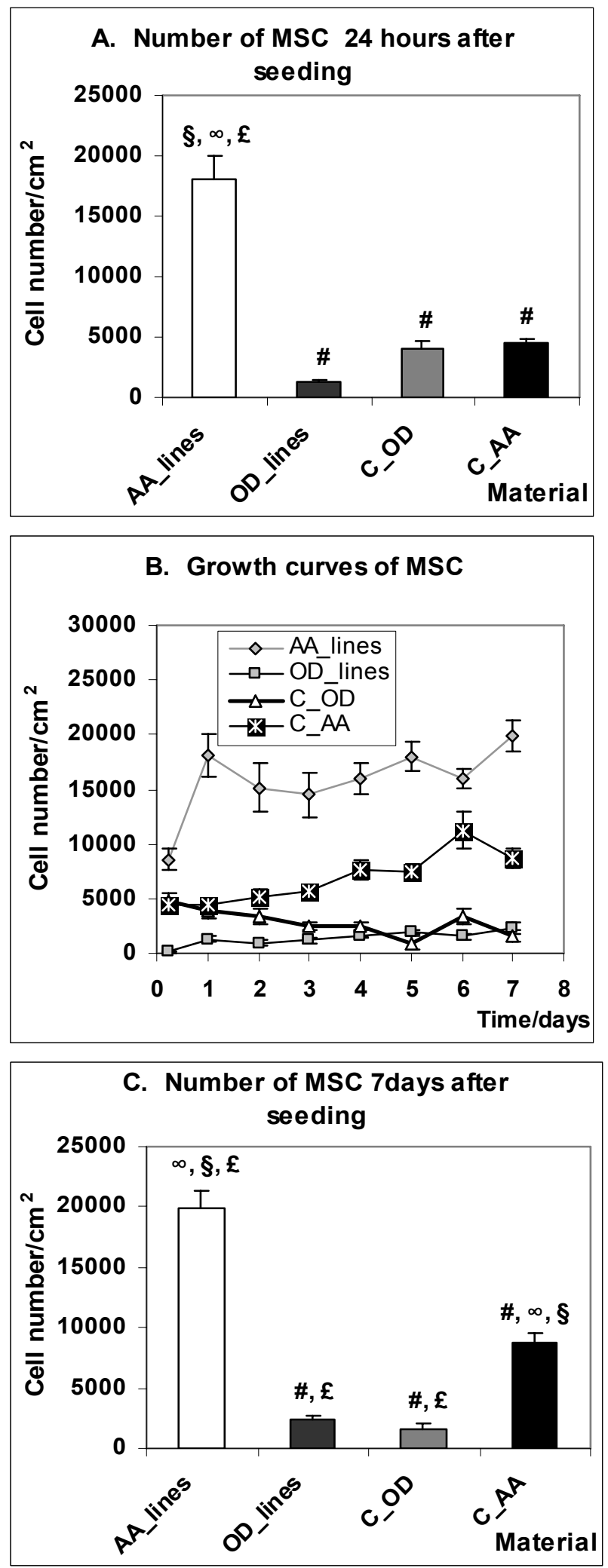

Fig. 5. Population density of mesenchymal stem cells (MSC) on strips formed by AA (AA_lines), OD (OD_lines), on a control surface without microdomains formed by $A A$ (C_AA) and $O D$ (C_OD) on day 1 (A) and on day 7 after seeding (C). Growth curves (B) of MSC cultivated on these surfaces. Mean \pm SEM from 10 to 12 measurements, ANOVA; $\#, \S, £, \infty$ : $p \leq 0.05$ in comparison with AA_lines, OD_lines, C_AA and C_OD, respectively.
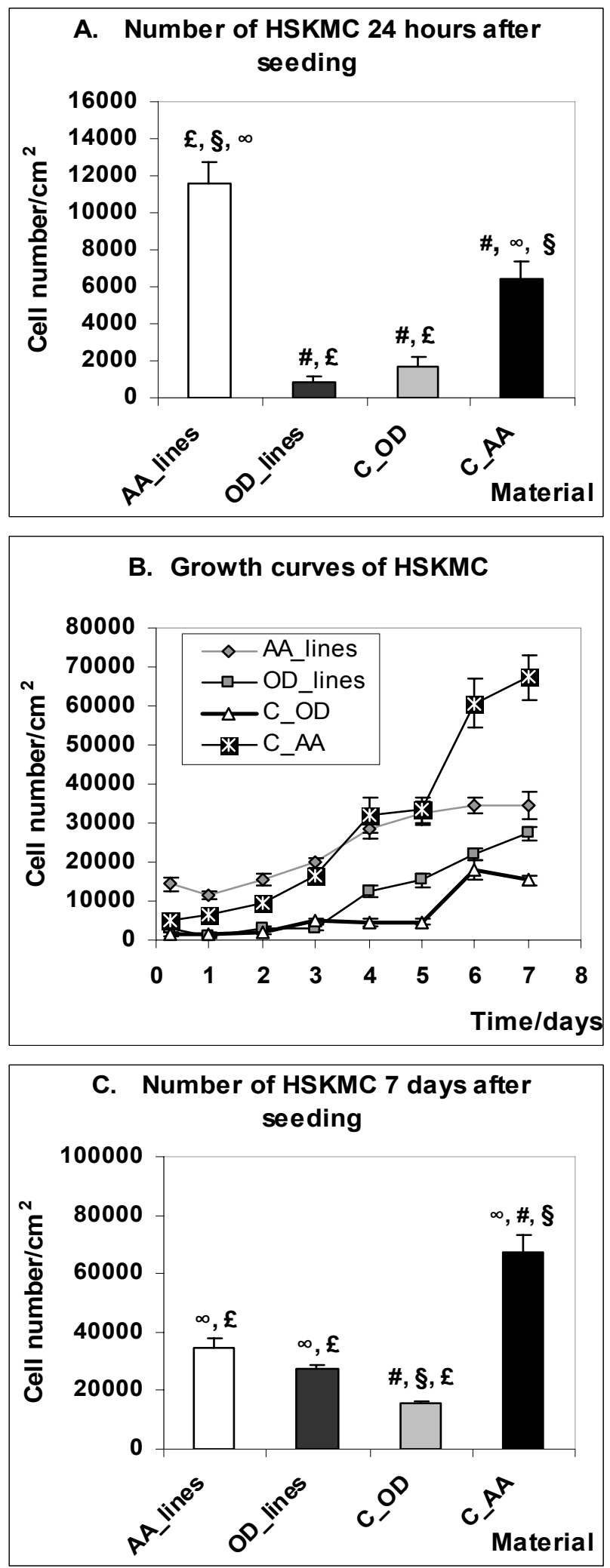

Fig. 6. Population density of human skeletal muscle cells (HSKMC) on strips formed by AA (AA_lines), OD (OD_lines), on a control surface without microdomains formed by AA (C_AA) and OD (C_OD) on day 1 (A) and on day 7 after seeding (C). Growth curves (B) of HSKMC cultivated on these surfaces. Mean \pm SEM from 12 to 17 measurements, ANOVA; \#, $, £, \infty: p \leq 0.05$ in comparison with AA_lines, OD_lines, C_AA and C_OD, respectively. 
the cell-cell contacts. The highest concentration of CD44 in the area of cell-cell contacts was also apparent on micropatterned surfaces, but usually not on the pure C_AA surfaces (Figs 7G-I). At the same time, the cells on C_OD displayed less developed talin-containing focal adhesion plaques (Figs 7J-L).

Beta-actin cytoskeleton was better developed and organized into thick bundles in MSC cultured on pure AA than on OD (Figs 7M-O). In comparison with cells on OD surfaces, HSKMC on AA domains, and especially on continuous C_AA surfaces, contained stronger alpha-actin filaments organized in parallel bundles (Figs 7P-R). However, such a clear difference between the AA surface and the OD surface was not observed when the cells were stained for beta-actin (data not shown).

Concentration of alpha-actin, von Willebrand factor, beta-actin, CD44 and talin

As revealed by ELISA, the concentration (per $\mathrm{mg}$ of protein) of alpha-actin, a marker of differentiation of muscle-type cells, such as VSMC and HSKMC, was significantly higher in VSMC growing on C_AA than growing on C_OD. However, in HSKMC, the concentrations of alpha-actin in cells growing on $\mathrm{C}_{-} \mathrm{AA}$ and C_OD were similar. The concentration of von Willebrand factor, a marker of endothelial cell maturation, was also similar in EC on C_AA and C_OD (Table 1). Interestingly, MSC growing on C_OD contained significantly more CD44 than cells growing on C_AA. At the same time, the concentration of beta-actin in MSC growing on C_OD was significantly lower than in MSC on C_AA. The concentrations of beta-actin in VSMC, EC and HSKMC, as well as talin in all cell types were similar in cells growing on both $\mathrm{C}_{-} \mathrm{AA}$ and $\mathrm{C}_{-} \mathrm{OD}$ surfaces.

\section{Discussion}

We created surfaces patterned with strip-like domains of acrylic acid (AA) and 1, 7-octadiene (OD) characterized with preferential adhesion and growth of vascular smooth muscle cells (VSMC), endothelial cells (EC), mesenchymal stem cells (MSC) and skeletal muscle cells (HSKMC) on AA domains. This preferential cell colonization was probably due to a higher content of oxygen-containing chemical functional groups on these domains (Bačáková et al. 2000, 2001). This content is negatively correlated with the fragmentation of the polymer during plasma treatment, followed by crosslinking of the fragments. The most important parameter for regulating the process of fragmentation is plasma power. The highest fragmentation was observed at plasma power higher than $20 \mathrm{~W}$ (Alexander and Duck 1998, 1999). Thus, we used lower values of plasma power, $10 \mathrm{~W}$ and $5 \mathrm{~W}$, for OD and $\mathrm{AA}$, respectively, in order to provide sufficient functionality and also stability of the polymer. XPS measurement of AA on our samples revealed the presence of more than $10 \%$ of $-\mathrm{COO}-\mathrm{R} / \mathrm{H}$ groups after AA polymerization. The positive influence of $-\mathrm{COOH}$ groups on cell attachment on the surface composed of acrylic acid/1,7-OD copolymer was observed in a study on osteoblast-like cells (ROS17/2.8) and human keratinocytes. The best attachment was observed on surfaces with $3 \%$ and $2.3 \%$ of $-\mathrm{COOH}$ group on the surface layer, respectively (Daw et al. 1998, France et al. 1998). Similarly, in our earlier study performed on VSMC cultured on polylactide/ poly(ethylene oxide)-based surfaces, we observed slightly improved adhesion and proliferation of VSMC on surfaces bearing - $\mathrm{COOH}$ (Bačáková et al. 2003). Also other oxygen-containing groups, such as $-\mathrm{C}=\mathrm{O},-\mathrm{C}-\mathrm{O}-$ $\mathrm{H} / \mathrm{R}$ and $-\mathrm{C}-\mathrm{O}-\mathrm{C}-$, produced during the plasma polymerization process, could contribute to the improved adhesion of VSMC and EC to AA surfaces (Bačáková et al. 2000, 2001).

The presence of oxygen-containing groups on the biomaterial surface is usually associated with its increased wettability (Bačáková et al. 2000, 2001, 2003). In accordance with these findings, our AA surfaces were more hydrophilic than OD, although the contact angle of polymerized AA measured in the previous study was as low as $17^{\circ}$ (Bullett et al. 2003). Highly hydrophilic surfaces are known for low or even absent adsorption of proteins from the culture media or body fluids, including cell adhesion-mediating extracellular matrix proteins, namely vitronectin, fibronectin, collagen and laminin. Our results confirmed that collagen IV, an important component of cellular basal lamina, was adsorbed preferably on hydrophobic OD regions. In another study, collagen was adsorbed in a higher amount on more hydrophobic polystyrene than on plasma-oxidized and more hydrophilic polymer (PSox). However, collagen layers adsorbed on PSox were smoother and showed higher mechanical stability (Pamula et al. 2004). Improved mechanical properties together with an appropriate spatial conformation of the adsorbed proteins could also contribute to the preferential cell adhesion on 


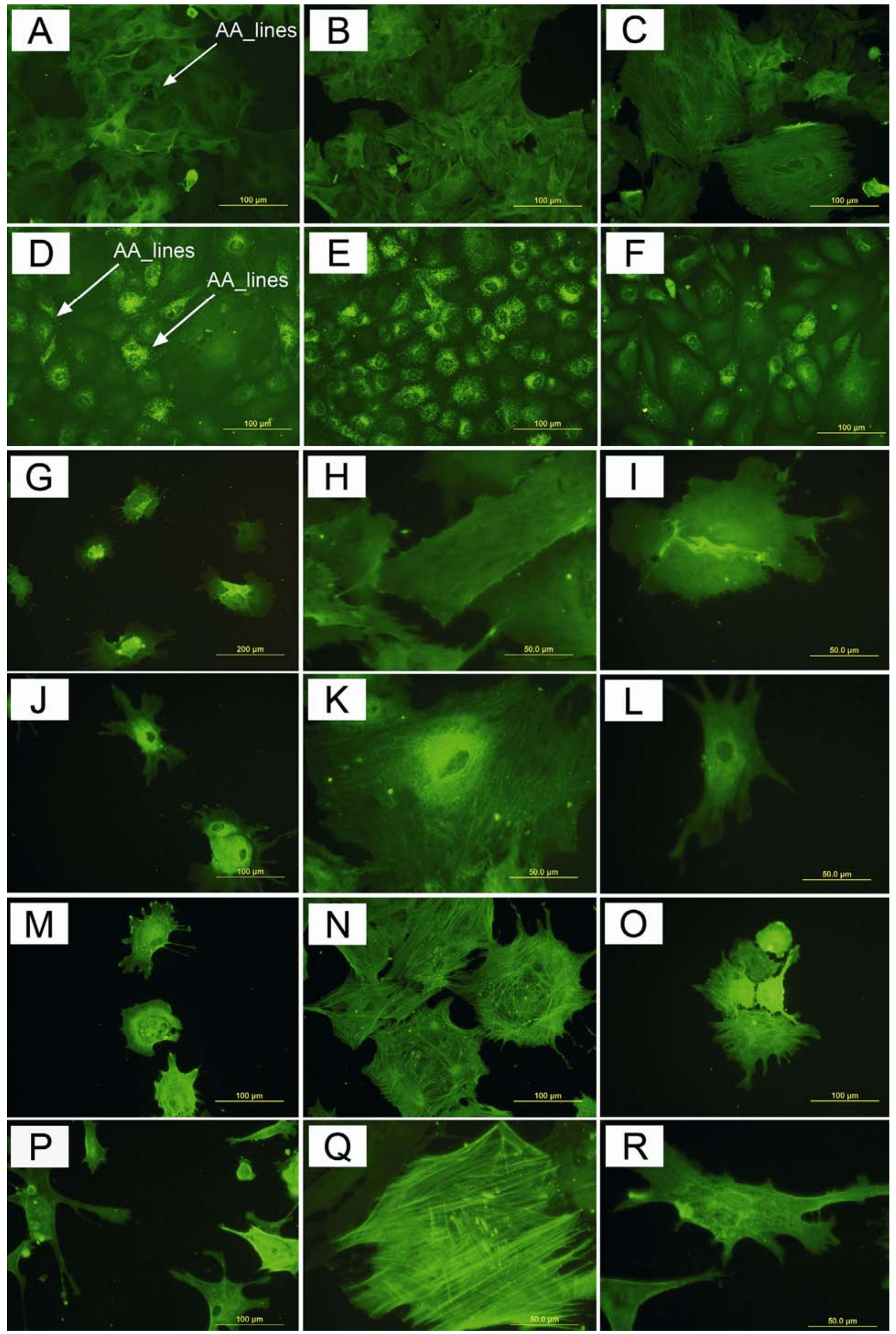


Fig. 7. Immunofluorescence staining of alpha-actin in vascular smooth muscle cells (A-C); von Willebrand factor in endothelial cells (D-F), CD44 (G-I), talin (J-L) and beta-actin (M-O) in mesenchymal stem cells; and alpha-actin in skeletal muscle cells (P-R) growing on domains composed of acrylic acid $(\mathbf{A}, \mathbf{D}, \mathbf{G}, \mathbf{J}, \mathbf{M}, \mathbf{P})$, pure acrylic acid $(\mathbf{B}, \mathbf{E}, \mathbf{H}, \mathbf{K}, \mathbf{N}, \mathbf{Q})$, and pure 1,7-octadiene $(\mathbf{C}, \mathbf{F}, \mathbf{I}, \mathbf{L}, \mathbf{O}, \mathbf{R})$. Olympus IX50, digital camera DP70, obj.×20x, bar=100 $\mu \mathrm{m}(\mathbf{A}-\mathbf{F}, \mathbf{J}, \mathbf{M}-\mathbf{P}) ;$ obj. $\times 10(\mathrm{G})$, bar=200 $\mu \mathrm{m}$; and obj. $\times 40$, bar=50 $\mu \mathrm{m}(\mathbf{H}, \mathbf{I}$, $\mathbf{K}, \mathbf{L}, \mathbf{Q}, \mathbf{R})$.

hydrophilic AA. Moreover, in our cell culture system, the selectivity of cell adhesion may be further enhanced by competitive adsorption of plasma proteins. It is known that albumin, which is non-adhesive for cells, is adsorbed preferentially to hydrophobic surfaces, whereas fibronectin, a cell adhesion-mediating protein, is adsorbed in an active conformation (accessible for cell adhesion receptors) only on hydrophilic surfaces (Dewez et al. 1999). Similarly, the amount of immunoglobulin G adsorbed onto $\mathrm{COOH}$-functionalized surfaces was lower, but this protein was better accessible for antibodies (Bullett et al. 2003).

On the other hand, the addition of a small amount of albumin to a fibronectin solution improved fibronectin conformation on a hydrophobic surface (Grinnell and Feld 1982). This may explain our finding that hydrophobic OD surfaces were not completely antiadhesive for cells.

Goessl et al. (2001) revealed that VSMC needed a minimum area of $400 \mu \mathrm{m}^{2}$ for attachment and spreading, and larger areas were often occupied by more cells, which created cell agglomerates where individual cells were overlapped. This is in accordance with our results that VSMC grew in very high density on relatively wide AA strips with the area ranging from approx. 94,000 to $300,000 \mu \mathrm{m}^{2}$. EC derived from human tendon granuloma and cultivated on nanostructured poly(4-bromostyrene) increased and accelerated their spreading and changed their shape to arcuate or curved, which is considered to be more natural (Dalby et al. 2002). On our micropatterned samples, we observed more elongated morphology of EC, which is often observed in three-dimensional cultivating systems (Davis et al. 2002). In addition, this morphology is a sign of immature, proliferating endothelium, e.g. during angiogenesis (Davis et al. 2002). A certain immaturity of endothelial cells may explain our finding that the endothelial cells on AA surfaces were not able to increase significantly their content of von Willebrand factor, which is a marker of EC differentiation. Another cause may be the line origin of our EC, which could be associated with some irreversible loss of cell differentiation markers (Fisher and Tickle 1981). On the other hand, immunofluorescence revealed that in cells on AA surfaces, von
Willebrand factor was better organized into WeibelPalade bodies. On AA, not only did we observe preferential adhesion of VSMC but this in turn led to an increase in protein synthesis of alpha-actin. The higher concentration of alpha-actin in VSMC seems to be an advantageous property for the maintenance of VSMC in differentiated contractile phenotype, which is necessary for their proper functions on artificial vessels.

Preferential cell colonization on hydrophilic AA domains was further enhanced by additional cell migration from adjacent hydrophobic regions. Both EC and VSMC are able to produce chemotactic and growth factors such as HB-EGF, bFGF, TGF- $\beta 1$, PDGF-AA, and PDGF-BB, which regulate their migration, proliferation and phenotypic modulation (Raab and Klagsbrun 1997, von Offenberg Sweeney et al. 2004).

Mesenchymal stem cells were most sensitive to the physical and chemical surface properties during the entire cultivation period, as indicated by the highest regional selectivity of their adhesion and growth on AA domains. This might be due to their relatively low maturation status and thus high responsiveness to extracellular signals controlling their growth and differentiation (Engler et al. 2006). Another possible cause might be that these cells proliferated very slowly, and thus they were not able to grow out of AA lines and span adjacent OD lines like VSMC. On continuous C_OD surfaces, MSC increased their synthesis of CD44, a receptor for hyaluronic acid. This could be explained as a compensatory mechanism to improve cell adhesion on a surface that is less convenient for cell adhesion, as indicated by less developed talin-containing focal adhesion plaques in MSC on C_OD. The preferential localization of CD44 at the regions of cell-cell contacts suggests that this compensatory mechanism involves enhancement of cell-cell adhesion (Yang and Binns 1993). Activated CD44 receptor is known to induce actin polymerization (Bourguignon et al. 2007). However, in MSC on C_OD surfaces, the organization of beta-actin into cytoskeletal fibres and even its concentration was lower than in cells on C_AA surfaces.

Interestingly, on continuous non-patterned C_AA surfaces, skeletal muscle HSKMC cells reached an almost twice higher population density than on AA_strips 
on day 7 after seeding. This could be explained by the fact that continuous C_AA surfaces offered a larger area, more favorable for cell adhesion and growth than relatively narrow AA strips. In addition, the skeletal muscle cells are able to synthesize growth factors like IGF-1 and IGF-II (Semsarian et al. 1999). The concentrations of these factors in cultures on $\mathrm{C}_{-} \mathrm{AA}$ might be higher because the total number of HSKMC cells in these cultures was higher from the onset of cultivation. The enhanced growth of HSKMC cells on C_AA surfaces was accompanied by a more pronounced organization of alpha-actin molecules into thick filaments oriented in parallel. In muscle cells, organization of alpha-actin could be considered as a sign of maturation and acquisition of contractile phenotype. On the other hand, the concentration of alpha-actin in cells on $\mathrm{C}_{-} \mathrm{AA}$ was similar as on C_OD.

Micropatterned surfaces can be practically used in construction of tissue replacements and tissue engineering. For example, microtextured polyurethane seeded with EC exposed to shear stress using a dynamic cultivation system was able to increase significantly (by $36 \%$ ) the retention of EC compared to non-patterned polyurethane surface (Daxini et al. 2006). This suggests that the patterned surfaces developed in this study might be used for constructing bioartificial vascular grafts, where it is highly desirable to coat the inner surface with a continuous endothelial cell layer. Another example is provided by the two- and three-dimensional micropatterned thermoresponsive surfaces used for coculture of hepatocytes and endothelial cells for potential construction of bioartificial liver tissue (Hirose et al. 2000).

\section{Conclusions}

We have constructed micropatterned surfaces containing hydrophilic and hydrophobic strip-like domains prepared by plasma polymerization of acrylic acid (AA) and 1,7-octadiene (OD), respectively. Four cell types, represented by rat vascular smooth muscle cells (VSMC), bovine vascular endothelial cells (EC), porcine mesenchymal stem cells (MSC) and human skeletal muscle cells (HSKMC) preferentially recognized the hydrophilic AA domains for their adhesion and growth. However, these cell types differed in their responses, such as their shape, cytoskeletal organization, maturation and proteosynthesis. VSMC and EC were more elongated along AA strips, whereas the other cell types were round or polygonal. Actin cytoskeleton was better organized in MSC and HSKMC on AA. Cells on AA were usually more mature, as indicated by stronger staining for von Willebrand factor (EC), thick alpha-actin filaments (HSKMC) and a higher concentration of alpha-actin (VSMC). MSC on OD domains synthesized more CD44, a receptor for hyaluronic acid. Therefore, the patterned surfaces provide a control over spatial distribution as well as adhesion, growth and differentiation behavior of cell. Thus, they have significant potential for applications in tissue engineering, as information on the ability to influence cell distribution using surface chemical group deposition will be of value in developing 3-dimensional tissue constructs.

\section{Conflict of Interest}

There is no conflict of interest.

\section{Acknowledgements}

The study was supported by the Academy of Sciences of the Czech Republic (grants No. A 5011301 and KAN 101120701). We also thank Mrs. Ivana Zajanová (Inst. Physiol., Acad. Sci. CR) for her excellent technical assistance and Mr. Robin Healey (Czech Technical University, Prague) for the language revision of the manuscript.

\section{References}

ALEXANDER MR, DUC TM: A study of the interaction of acrylic acid/1,7-octadiene plasma deposits in water and other solvents. Polymer 40: 5479-5488, 1999.

ALEXANDER MR, DUCK TM: The chemistry of deposits formed from acrylic acid plasmas. J Mat Chem 8: 937-943, 1998.

BAČÁKOVÁ L, KUNEŠ J: Sex-dependent differences in growth of vascular smooth muscles cells from spontaneously hypertensive rats. Physiol Res 44: 127-130, 1995.

BAČÁKOVÁ L, MAREŠ V, LISÁ V, ŠVORČÍK V: Molecular mechanisms of improved adhesion and growth of an endothelial cell line cultured on polystyrene implanted with fluorine ions. Biomaterials 21: 1173-1179, 2000. 
BAČÁKOVÁ L, WALACHOVÁ K, ŠVORČÍK V, HNATOWITZ V: Adhesion and proliferation of rat vascular smooth muscle cells (VSMC) on polyethylene implanted with $\mathrm{O}^{+}$and $\mathrm{C}^{+}$ions. $J$ Biomater Sci Polym Ed 12: 817-834, 2001.

BAČÁKOVÁ L, LAPČÍKOVÁ M, KUBIES D, RYPÁČEK F: Adhesion and growth of rat aortic smooth muscle cells on lactide-based polymers. Adv Exp Med Biol 534: 179-189, 2003.

BAČÁKOVÁ L, FILOVÁ E, RYPÁČEK F, ŠVORČÍK V, STARÝ V: Cell adhesion on artificial materials for tissue engineering. Physiol Res 53 (Suppl 1): 35-45, 2004.

BOURGUIGNON LY, PEYROLLIER K, GILAD E, BRIGHTMAN A: Hyaluronan-CD44 interaction with neural Wiskott-Aldrich syndrome protein (N-WASP) promotes actin polymerization and ErbB2 activation leading to beta-catenin nuclear translocation, transcriptional up-regulation, and cell migration in ovarian tumor cells. J Biol Chem 282: 1265-1280, 2007.

BRIGGS D: Surface Analysis of Polymers by XPS and Static SIMS. Cambridge University Press, 1998, pp 65-66.

BULLETT NA, WHITTLE JD, SHORT RD, DOUGLAS CWI: Adsorption of immunoglobulin G to plasma-copolymer surface of acrylic acid and 1,7-octadiene. J Mater Chem 13: 1546-1553, 2003.

DALBY MJ, RIEHLE MO, JOHNSTONE H, AFFROSSMAN S, CURTIS AS: In vitro reaction of endothelial cells to polymer demixed nanotopography. Biomaterials 23: 2945-2954, 2002.

DAVIS GE, BAYLESS KJ, MAVILA A: Molecular basis of endothelial cell morphogenesis in three-dimensional extracellular matrices. Anat Rec 268: 252-275, 2002.

DAW R, CANDAN S, BECK AJ, DEVLIN AJ, BROOK IM, MACNEIL S, DAWSON RA, SHORT RD: Plasma copolymer surface of acrylic acid/1,7-octadiene: surface characterisation and the attachment of ROS 17/2.8 osteoblast-like cells. Biomaterials 19: 1717-1725, 1998.

DAXINI SC, NICHOL JW, SIEMINSKI AL, SMITH G., GOOCH KJ, SHASTRI VP: Micropatterned polymer surfaces improve retention of endothelial cells exposed to flow-induced shear stress. Biorheology 43: 44-45, 2006.

DEWEZ JL, DOREN A, SCHNEIDER YJ, ROUXHET PG: Competitive adsorption of proteins: key of the relationship between substratum surface properties and adhesion of epithelial cells. Biomaterials 20: 547-559, 1999.

ENGLER AJ, SEN S, SWEENEY HL, DISCHER DE: Matrix elasticity directs stem cell lineage specification. Cell 126: 677-689, 2006.

FISHER PE, TICKLE C: Differences in the alignment of normal and transformed cells on glass fibres. Exp Cell Res 131: 407-409, 1981.

FRANCE RM, SHORT RD, DAWSON RA, MACNEIL S: Attachment of human keratinocytes to plasma co-polymers of acrylic acid/octa-1,7-diene and allyl amine/octa-1,7-diene. J Mater Chem 8: 37-42, 1998.

GOESSL A, BOWEN-POPE DF, HOFFMAN AS: Control of shape and size of vascular smooth muscle cells in vitro by plasma lithography. J Biomed Mater Res 57: 15-24, 2001.

GRINNELL F, FELD MK: Fibronectin adsorption on hydrophilic and hydrophobic surfaces detected by antibody binding and analyzed during cell adhesion in serum-containing medium. J Biol Chem 257: 4888-4893, 1982.

HADDOW DB, FRANCE RM, SHORT RD, DAWSON RA, LEGGET GJ, COOPER E: Comparison of proliferation and growth of human keratinocytes on plasma copolymers of acrylic acid/1,7-octadiene and self-assembled monolayers. J Biomed Mater Res 47: 379-387, 1999.

HADDOW DB, STEELE DA, SHORT RD, DAWSON RA, MACNEIL S: Plasma-polymerized surfaces for culture of human keratinocytes and transfer of cells to an in vitro wound-bed model. J Biomed Mater Res 64A: 80-87, 2003.

HIROSE M, YAMATO M, KWON OH, HARIMOTO M, KUSHIDA A, SHIMIZU T, KIKUCHI A, OKANO T: Temperature-responsive surface for novel co-culture systems of hepatocytes with endothelial cells: 2-D patterned and double layered co-cultures. Yonsei Med J 41: 803-813, 2000.

KETTLE AP, BECK AJ, O'TOOLE L, JONES FR, SHORT RD: Plasma polymerisation for molecular engineering of carbon-fibre surfaces for optimised composites. Comp Sci Technol 57: 1023-1032, 1997.

PAMULA E, DE CUPERE V, DUFRENE YF, ROUXHET PG: Nanoscale organization of adsorbed collagen: Influence of substrate hydrophobicity and adsorption time. J Colloid Interface Sci 271: 80-91, 2004.

RAAB G, KLAGSBRUN M: Heparin-binding EGF-like growth factor. Biochim Biophys Acta 1333: F179-F199, 1997. 
SEMSARIAN C, SUTRAVE P, RICHMOND DR, GRAHAM RM: Insulin-like growth factor (IGF-I) induces myotube hypertrophy associated with an increase in anaerobic glycolysis in a clonal skeletal-muscle cell model. Biochem J 339: 443-451, 1999.

VON OFFENBERG SWEENEY N, CUMMINS PM, BIRNEY YA, REDMOND EM, A. CAHILL PA: Cyclic straininduced endothelial MMP-2: role in vascular smooth muscle cell migration. Biochem Biophys Res Commun 320: $325-333,2004$.

YANG H, BINNS RM: CD44 is not directly involved in the binding of lymphocytes to cultured high endothelial cells from peripheral lymph nodes. Immunology 79: 418-424, 1993. 